\title{
Spatial planning, nationalism and territorial politics in Europe
}

\section{Final version dated 13.03.2020 accepted for publication in Regional Studies}

\section{Authors:}

\section{Claire Colomb}

Professor of Urban Studies and Planning

The Bartlett School of Planning

University College London (UCL)

Central House, 14 Upper Woburn Place

London WC1H ONN,

UK

Email: c.colomb@ucl.ac.uk

https://iris.ucl.ac.uk/iris/browse/profile?upi=CMCOL44

\author{
John Tomaney \\ Professor of Urban and Regional Planning \\ University College London, The Bartlett School of Planning \\ The Bartlett School of Planning \\ University College London (UCL) \\ Central House, 14 Upper Woburn Place \\ London WC1H ONN \\ UK \\ Email: j.tomaney@ucl.ac.uk \\ https://iris.ucl.ac.uk/iris/browse/profile?upi=JTOMA80
}

Keywords: Scotland, Catalonia, Flanders, spatial planning, sub-state nationalism, regionalism

Abstract: The paper explores whether spatial planning, infrastructure and territorial management issues and policies are an important field of mobilisation for nationalist actors in European sub-state contexts characterised by demands for more autonomy or independence: Scotland, Catalonia and Flanders. We show that such issues are sometimes mobilised to support the autonomist or separatist political agendas of sub-state nationalist parties, but that this varies significantly in the three cases, due to the different political ideologies of each nationalist party vis-à-vis the role of the state and the legitimacy of public policy interventions in private property, land development and market processes. 


\section{Introduction}

Over the past decade nationalist parties have gained power at the regional level (alone or in coalitions) and augmented their claims for more autonomy or independence in a number of European countries. This resurgence of sub-state nationalism concerns the recasting of the 'politics of territorial solidarity' (Béland and Lecours, 2008). Although cultural claims and identity narratives remain important in regionalist and sub-state nationalist politics, challenges to existing constitutional and fiscal arrangements increasingly mobilise an economic discourse - a language of efficiency, competitiveness and good governance - as the basis of demands for more autonomy or independence (Rodríguez-Pose and Sandall, 2007). Simultaneously, new discourses about social policy and infrastructure requirements are promoted by nationalist parties to demand decentralisation of power and resources (Béland and Lecours, 2008; Colomb, et al., 2014).

Despite these trends, little academic attention has been paid to the link between sub-state nationalist claims and spatial planning, infrastructure and territorial management policies, even if the management of land use and territory is based on cultural and political choices about the built and natural environment, in which particular 'models of society' are materialised (Faludi, 2007). We should expect spatial planning to be an arena through which nationalist political actors (parties and civic movements) ${ }^{1}$ invoke a distinctive 'collective territorial imagination' (Peel and Lloyd, 2007), and seek to distinguish the present, and future, character of their territory. In this paper we explore how spatial planning is mobilised by nationalist actors, through which they may seek to envision and shape their territory in substate contexts characterised by demands for more autonomy or independence. Specifically, we examine the territorial politics of spatial planning in Scotland (United Kingdom), Catalonia (Spain), and Flanders (Belgium). All three territories have achieved significant degrees of selfgovernment, notably in spatial planning and cognate fields.

In contrast to traditional 'land-use planning' which is limited to the regulation of land and property uses, the location of activities and the control of development at the local scale, 'spatial planning' as a state activity engages with complex, multifaceted problems in an integrated way and aims to envision shared territorial futures. It seeks to balance demands for economic development, environmental protection and social and territorial equity through the distribution of key infrastructure and collective amenities, to protect areas of natural, environmental or historic value, and to co-ordinate the spatial impacts of sectoral policies such as transport, housing, and economic development (e.g. Albrechts, et al. 2003). The reality of planning policies and practices often differs, however, from this ideal definition of 'spatial planning'. Planning is an intrinsically political activity, shaped by shifting ideologies, governmental agendas and interest presentation, and attendant conflicts on the relationship between state, market and civil society (Nadin and Stead, 2008). Any form of (public) planning is an attempt to influence social, economic and environmental processes through various forms of regulation, policy instruments and modes of state action. Redistributive conflicts are at the heart of planning, which deals with fundamentally 'wicked problems' (Rittell and Webber, 1973) requiring trade-offs that benefit some interests and social groups at the expense of others (Campbell, 1996).

Below, we first review literature from a range of disciplines on the relationship between spatial planning (and territorial management activities), nation-building, state formation, regional decentralisation, and (sub-state) nationalist claims. We note the virtual silence in 
classical studies of nationalism on how public policies shape the organisation of territory, a gap which this paper addresses. Second, we consider each of our cases in turn, analysing the extent to which nationalist parties have mobilised spatial planning and territorial management issues in their discourses, and whether they have developed distinctive planning and territorial management policy agendas as part of their claims. Finally, we identify similarities and differences between the three cases, outline possible explanatory factors and ponder further research.

\section{Envisioning the nation: spatial planning and territorial politics in contested states}

\section{Planning and the making of national state territories in Europe}

If the nation is an 'imagined community' (Anderson, 1993), it is materialised in canals and ports, roads and railways, electricity grids and reservoirs. Long before the field of 'planning' was codified into extensive legislation, modern state formation involved the creation of postal services, statistical offices, cadastral and mapping exercises (Gellner, 1993; Scott, 1998). The planning and construction of strategic transport and communications infrastructure, together with the provision of public services, was a vital component of state-building in Europe (Williams and Smith, 1983). In France after 1870, as Eugen Weber (1976: 218) memorably states, roads and railways 'welded several parts into one' and turned 'peasants into Frenchmen'. Such infrastructure planning connected, bounded, subdued and unified the territory 'to assimilate or incorporate culturally distinctive territories' via a process of 'state building nationalism' (Breuilly, 1993). Similar practices were witnessed in Spain (Bel, 2010, 2011), the UK (Hewitt, 2011), and Belgium (De Vries, 2015), albeit reflecting variable national configurations of political and social forces.

In the $20^{\text {th }}$ century, forms of territorial planning were instrumental in the formation and consolidation of 'Keynesian welfare states', alongside national demand management and social programmes which in Europe took a range of forms (Brenner, 2004). The provision of collective goods such as public housing, education and transport was intended to achieve social and territorial cohesion and required planning on a large scale. 'Spatial Keynesianism' typically involved the centralisation of regulatory capacities, the creation of uniform systems of local government and efforts to equalise public investment and infrastructure across the territory. But the way states have intervened to shape economy, society and the territory varies from country to country (Esping-Andersen, 1990). In planning studies, this is reflected in attempts to compare, classify and typologise national planning systems, practices and cultures in Europe (e.g. Newman and Thornley, 1996; CEC, 1997; Nadin and Stead, 2008; Knieling and Othengrafen, 2009).

The unifying ambitions of the central state were always frustrated, however, in part because 'high modernist schemes in liberal democratic settings must accommodate themselves sufficiently to local opinion in order to avoid being undone at the polls' (Scott, 1998: 102). 'Spatial Keynesianism' became destabilised by processes of economic restructuring unfolding from the 1970s onwards, which reinforced some pre-existing 'centre-periphery' cleavages which historic processes of national state formation had not erased (Rokkan and Urwin, 1983). Demands for decentralisation emerged or intensified in many West European countries and led to reforms of uneven pace and scope. Decentralisation to the 'meso-level' 
of regions has been driven by various factors (Keating, 2013), not least by regionalist electoral insurgencies reflecting a contested 'territorial politics' (Keating, 2008). But decentralisation reforms did not quench demands for more autonomy: over the recent decades, in several European countries, regionalist/nationalist parties have won power at the regional level and strengthened their claims for increased autonomy or even outright independence, as we will see later.

\section{(Sub-state) nationalism and the making of the territory}

Nationalism is 'an ideological movement for attaining and maintaining autonomy, unity and identity for a population which some of its members deem to constitute an actual or potential "nation"' (Smith, 2001: 9). A nation, meanwhile, is 'a named human community occupying a homeland, and having common myths and a shared history, a common public culture, a single economy and common rights and duties for all members' (Ibid.: 13). Nation and state are not necessarily congruent - there are many 'stateless nations' and some multinational states. In classical discussions of nationalism, it is notable that the role of 'territory' is frequently omitted, or merely treated as a container for a (latent or existing) nation, whose borders may be contested. Smith (2001), however, emphasises the threefold importance of "homeland" in the emergence of nationalist claims. First, homeland acts

as a title-deed, a political claim to a specified area of land and its resources, often in the teeth of opposition from rival claimants. From this perspective, the homeland is indispensable for economic well-being and physical security; and the exploitation of its agricultural and mineral resources becomes a prime nationalist consideration (p. 3132).

Second, 'the homeland constitutes an historic territory, the ancestral land' of the people and the setting for 'foundational' historical events (and their sites of memory). Third, he highlights the profound effect of "landscapes" (and their representations) on the self-understanding of members of the nation.

According to Etherington $(2003,2010)$, the neglect of territory in foundational studies of nationalism is attributable to the tendency to naturalise the relationship between the two, and to focus on the temporal, rather than the spatial/geographical dimension of nationbuilding (2010: 323). 'National territorial belonging' is a distinctly modern phenomenon (Billig, 1995), shaped by the practices of states in 'territory making' and in the 'naturalisation of links between territories and people' (Paasi, 1997: 41). This is achieved, firstly, through the incorporation of physical features of the territory into representations of national identity and secondly, at a symbolic level, through nationalist (re)interpretations of the territory fusing the homeland with elements of identity such as culture, language, common myths and history, religious buildings, fields or even trees (Etherington, 2010). Among the instruments that have been used to legitimate nationalist territorial claims and promote territorial belonging are geography teaching, cartography (Agnew, 1987; Nogué, 1998), practices such as hiking; or the celebration and reproduction of landscapes in painting, poems, songs (Schama, 1995; Hooson, 1998; Nogué and Vicente, 2004).

Williams and Smith (1983) additionally emphasise how the remaking of the environment is a key part of nationalist projects:

The manner in which nationalists 'activate' and mould their territories to fit their visions - the construction of ports and waterways, the regulation of law and rights, the use of development plans for industrialization, the strengthening of borders, the construction 
of tariffs, the use of settlements, communication networks and trade flows to alter the physical and occupational balance within a territory testify to the shaping of 'national' space economies' (p. 514).

Additionally, the relationships between urban and rural areas, between city and country, have often been recurring themes in (sub-state) nationalist debates ( $\mathrm{Nel} \cdot \mathrm{lo}, 2013$ ). The conservative Catalanist cultural-political movement of the early $20^{\text {th }}$ century, for example, was rooted in a mystified image of rural life and shaped by a fear of the potential social and political upheaval brought about by 'revolutionary', working-class Barcelona the distrusted modern industrial city (Nel-lo, 2013; 2015). This later filtered into an insistence on decentralising population and activities from the city and "balancing" the territory. ${ }^{2}$

There are few studies of (sub-state) nationalism, however, that examine how public policies shape the territory and the organisation of the "homeland" - either the policies of the larger state whose authority and legitimacy is contested, or the policies proposed or developed by insurgent (sub-state) nationalist parties. This is important because, 'if state processes are a reflection of distinctiveness and national identity, planning as a state process should be a reflection of and motivation for identity and distinctiveness' (Allmendinger, 2001: 44). If nationalist ideologies and movements have 'well-defined goals of collective self-rule, territorial unification and cultural identity' (Smith, 2001: 21), spatial planning and territorial management policies should be crucial in achieving those ends, as well as operationalising "national" socio-economic projects materialised in space.

Béland and Lecours (2008) have shown that debates on social policy have become central to processes of sub-state identity formation and territorial mobilization, because this policy field represents a tangible manifestation of the existence of a political community. In contentious regions such as Québec, Scotland or Flanders, nationalist leaders suggest that autonomy or independence is needed because their population has distinctive social and economic preferences and constitutes a separate "world of welfare" (Esping-Andersen, 1990). Here, we consider the extent to which nationalist actors also argue that their population have different preferences in terms of spatial and territorial organisation, development and policies. Below, we analyse the extent to which nationalist parties have mobilised spatial planning and territorial management issues in their political discourses, and whether they have developed (distinctive) planning and territorial management policy agendas as part of their claims. Beforehand, however, we provide an overview of the current state of decentralisation, spatial planning, and territorial political conflicts in the three regions analysed in this paper.

\section{Decentralisation, regionalism/nationalism and spatial planning in Scotland, Catalonia and Flanders}

Over the past decades, Scotland, Catalonia and Flanders have asserted historical claims for autonomy within their respective states and experienced decentralisation (see Table 1). Each territory now has its parliament and government and a broadly similar range of administrative powers: in addition to key competences such as language, culture and education, these include fields which shape the organization of the territory, e.g. rural development, regional transport, local government, housing, environment, tourism, economic development, landuse and spatial planning. In each case, with some variation, the central state retains competences in constitutional matters, foreign affairs, defence, social security, immigration and nationality, energy regulation, key national infrastructure networks, and taxation. 
Table 1. Scotland, Catalonia and Flanders: basic institutional setting and planning system [Source: compiled by the authors]

\begin{tabular}{|c|c|c|c|}
\hline & Scotland (UK) & Catalonia (Spain) & Flanders (Belgium) \\
\hline Size & $\begin{array}{l}78,387 \mathrm{~km}^{2} \\
\text { UK: } 243,610 \mathrm{~km}^{2}\end{array}$ & $\begin{array}{l}32,114 \mathrm{~km}^{2} \\
\text { Spain: } 505,992 \mathrm{~km}^{2}\end{array}$ & $\begin{array}{l}13,522 \mathrm{~km}^{2} \\
\text { Belgium: } 30,528 \mathrm{~km}^{2}\end{array}$ \\
\hline Population & $\begin{array}{l}5.42 \text { million } \\
\text { (UK } 66.04 \text { million) } \\
\text { (mid-2017 estimate) }\end{array}$ & $\begin{array}{l}7.54 \text { million } \\
\text { (Spain } 46.73 \text { million) } \\
\text { (Jan. } 2018 \text { estimate) }\end{array}$ & $\begin{array}{l}6.55 \text { million } \\
\text { (Belgium } 11.38 \text { million) } \\
\text { (Jan. } 2018 \text { estimate) }\end{array}$ \\
\hline Density & 69 inhab./km² & 235 inhab. $/ \mathrm{km}^{2}$ & 484 inhab./km² \\
\hline Languages & English (Scottish Gaelic, Scots) & Catalan, Spanish & Flemish (Dutch) \\
\hline $\begin{array}{l}\text { Official structure of } \\
\text { the nation-state }\end{array}$ & $\begin{array}{l}\text { United Kingdom of Great Britain and } \\
\text { Northern Ireland: unitary parliamentary } \\
\text { constitutional monarchy with devolved } \\
\text { governments }\end{array}$ & $\begin{array}{l}\text { Kingdom of Spain: unitary parliamentary } \\
\text { constitutional monarchy with } \\
\text { 'autonomous communities' }\end{array}$ & $\begin{array}{l}\text { Kingdom of Belgium: federal } \\
\text { parliamentary constitutional monarchy }\end{array}$ \\
\hline $\begin{array}{l}\text { Key legislation for } \\
\text { regional autonomy }\end{array}$ & Scotland Act 1998 & $\begin{array}{l}\text { Spanish Constitution of 1978: right to } \\
\text { self-government of the 'nationalities and } \\
\text { regions of Spain' }=17 \text { autonomous } \\
\text { communities }+2 \text { autonomous cities. For } \\
\text { Catalonia: } 1979 \text { and } 2006 \text { Statutes of } \\
\text { Autonomy }\end{array}$ & $\begin{array}{l}\text { 1980, later expanded. } 3 \text { regions (Flanders, } \\
\text { Wallonia, Brussels Capital) + } 3 \text { linguistic } \\
\text { communities (Dutch, French, German). } \\
\text { Flemish community \& Flemish region are } \\
\text { merged }\end{array}$ \\
\hline $\begin{array}{l}\text { Institutions of } \\
\text { regional government }\end{array}$ & $\begin{array}{l}\text { Since 1999: } \\
\text { Scottish Parliament } \\
\text { Scottish Government headed by First } \\
\text { Minister }\end{array}$ & $\begin{array}{l}\text { Since 1979: } \\
\text { Parlament de Catalunya } \\
\text { Generalitat de Catalunya headed by a } \\
\text { President }\end{array}$ & $\begin{array}{l}\text { Since 1980: } \\
\text { Vlaams Parlement } \\
\text { Vlaamse Regering headed by a Minister- } \\
\text { President }\end{array}$ \\
\hline $\begin{array}{l}\text { Sub-administrative } \\
\text { units }\end{array}$ & $\begin{array}{l}32 \text { unitary authorities / local councils } \\
\text { (regional councils 1975-1996, abolished) }\end{array}$ & $\begin{array}{l}4 \text { provinces (Diputacions) } \\
41 \text { comarques (aggregations of } \\
\text { municipalities) } \\
947 \text { municipalities }\end{array}$ & $\begin{array}{l}5 \text { provinces } \\
22 \text { arrondissements } \\
308 \text { municipalities }\end{array}$ \\
\hline $\begin{array}{l}\text { Spatial planning } \\
\text { competence acquired }\end{array}$ & 1999 & 1979 & $1980 / 1988$ \\
\hline $\begin{array}{l}\text { Main spatial planning } \\
\text { legislation }\end{array}$ & $\begin{array}{l}\text { Town and Country Planning (Scotland) } \\
\text { Act } 1997 \text { Chapter } 8 \text { as amended by the } \\
\text { Planning etc (Scotland) Act } 2006\end{array}$ & $\begin{array}{l}\text { Llei de Política Territorial } 1983 \\
\text { Llei d'Urbanisme revised version of } 2010 \\
+ \text { various laws 2003-2010 }\end{array}$ & $\begin{array}{l}\text { Decrees on spatial planning of } 1996 \text { and } \\
1999 \text { (and revisions) }\end{array}$ \\
\hline $\begin{array}{l}\text { Strategic spatial } \\
\text { planning at the } \\
\text { regional level }\end{array}$ & $\begin{array}{l}\text { National Planning Framework (NPF) } \\
1^{\text {st }} \text { in } 2004,2^{\text {nd }} \text { in } 2008,3^{\text {rd }} \text { in } 2014\end{array}$ & $\begin{array}{l}\text { Pla Territorial General de Catalunya } 1995 \\
\text { Plans Territorials Sectorials }\end{array}$ & $\begin{array}{l}\text { Spatial Structure Plan for Flanders } 1997 \\
\text { New Spatial Policy Plan for Flanders in } \\
\text { preparation since } 2011\end{array}$ \\
\hline Sub-regional plans & $\begin{array}{l}4 \text { city-regional Strategic Development } \\
\text { Plans }\end{array}$ & 7 Plans Territorials Parcials & $\begin{array}{l}5 \text { Provincial Structure/Implementation } \\
\text { Plans }\end{array}$ \\
\hline Local plans & $\begin{array}{l}\text { Development Plans for } 32 \text { council areas } \\
\text { and } 2 \text { national parks }\end{array}$ & $\begin{array}{l}\text { Plans Directors Urbanistics (supra- } \\
\text { municipal) } \\
\text { Plans d'Ordenació Urbanística Municipal }\end{array}$ & $\begin{array}{l}\text { Municipal Structure } \\
\text { Plans/Implementation Plans }\end{array}$ \\
\hline
\end{tabular}


Comparative studies of the effect of regional decentralisation in Europe have tested whether new 'territorial policy communities' and divergent policy trajectories have emerged as a result (Keating, 2005, 2013; Keating et al., 2009). Political scientists have focused on fields such as social policy, culture, language and education, but much less so on spatial planning and territorial management policies. In parallel, in the field of planning studies, comparative approaches to planning systems in Europe have primarily focused on the national scale, neglecting how distinctive planning agendas and practices may emerge at other spatial scales. Yet decentralisation is generally seen to facilitate the operation of strategic spatial planning, providing frameworks of political accountability and enabling the promotion of regional social, cultural, and environmental assets in ways which central governments have failed to achieve (Albrechts et al., 2003). In Scotland, Catalonia and Flanders, the decentralisation of planning competences was reflected in the enactment of new legislation (see Table 1) and led to signs of divergence in approaches to territorial management, at least at the level of policy discourses. A shift to more strategic spatial planning was witnessed in all three cases.

In the UK, devolution has allowed greater experimentation in planning strategies and delivery styles, generating a diversity of 'spatial plannings' between and within the four nations of the UK (Tewdwr-Jones and Allmendiger, 2006; Allmendinger and Haughton, 2010; Colomb and Tomaney, 2015; Tomaney and Colomb, 2018). Scotland always remained a distinct jurisdiction with its own body of planning law. Planning reforms introduced by the first two Scottish governments after 1999 (Labour-Liberal Democrat coalitions) - notably the Planning, etc (Scotland) Act 2006 - were generally similar to those enacted in England and Wales by the then New Labour government (Lloyd and Peel, 2009). The electoral victory of the Scottish National Party (SNP) in Scotland in 2007, and of a Conservative-led coalition in the UK in 2010, contributed to a divergence in planning agendas between England and Scotland, with a promarket turn in the former and evidence of a more interventionist, pluralistic and corporatist policy-making approach in the latter (Tomaney and Colomb, 2013; 2018). The extent of this distinctiveness has, however, been debated (Keating, 2005; Allmendinger, 2006; Morphet and Clifford, 2014; Tomaney et al 2019).

Catalonia and Flanders have been described as pioneers in their country with regards to the emergence of more strategic approaches to planning. In Catalonia, between 2003 and 2010, while the Spanish government was promoting a deregulatory agenda, the regional government - led by a coalition of three left-wing parties - enacted several laws to create a wide-ranging system of spatial plans covering the whole territory, to protect coastal areas, tackle urban sprawl and support integrated urban regeneration in deprived neighbourhoods (Nel·lo, 2012). In Belgium, the decentralisation of planning competences led to divergent trajectories of spatial planning policies between the three regions. In Flanders, a shift from traditional land-use planning to new forms of strategic spatial planning was started by the CVP-SP-VU government (1991-1995) and then continued by the Christian Democrat-Socialist coalition (1995-1999) (Van den Broeck et al., 2014), in contrast to Wallonia where strategic spatial planning remained less developed. This was expressed by the 1997 Spatial Structure Plan for Flanders (Albrechts, 1999, 2001), which promoted polycentric development around the 'Flemish Diamond' (Brussels, Antwerp and Ghent), designated infrastructure corridors, and required urban growth boundaries to be drawn in order to halt sprawl (De Decker, 2011). The local planning permission system was tightened to restrict greenfield development (Van den Broeck and Verachtert, 2016). 
The link between decentralisation and the rise of new forms of - and agendas for - spatial planning is not straightforward, however. In Catalonia, the Generalitat had possessed spatial planning competences since 1979 but only exercised them in significant ways in the 2000s. In all three cases, the shift to a spatial planning approach was enacted when left-of-centre political parties or coalitions came to power, and was influenced by a new generation of academic and professional planners, as well as environmental and social movements (Albrechts, 1999; Nel·lo, 2003; Nogué and Wilbrand, 2010; Van den Broeck and Verachtert, 2016). This shift, as expressed in the case of Flanders by a senior planning scholar involved in the process of preparing the Spatial Structure Plan, encouraged different government departments to "reflect on what kind of [region] they wished".

Despite the high degree of decentralisation achieved in the three territories, none has reached a stable consensus about the distribution of powers between different tiers of government. In all three cases, nationalist parties attained power, in coalition governments or alone: in 1999 (and more markedly in 2004) in Flanders, in 2007 in Scotland and in 2010 in Catalonia. Moreover, the post-2008 economic crisis fuelled renewed claims about the 'politics of territorial solidarity'. Central government austerity reinforced Catalan demands for greater fiscal autonomy on the grounds that the region (which accounts for one fifth of Spanish economic output) returns more to the centre than it receives (Bel, 2015). In Belgium, Flemish nationalists argued that Flanders should not be subsidising poorer Wallonia. Under the 'Barnett formula', Scotland benefits from the system of financial allocation to the devolved administrations of the UK. But grievances about the exploitation of oil resources on Scottish territory was an important theme in the independence referendum debates in 2014, in the context of austerity imposed by the UK Conservative government since 2010 (which affects Scotland in fields such as social security). 
Table 2. Regional parties and governments in Scotland, Catalonia and Flanders, 1999-2019 [Source: compiled by the authors]

\begin{tabular}{|c|c|c|c|c|}
\hline & & Scotland & Catalonia & Flanders \\
\hline \multirow{4}{*}{$\begin{array}{l}\text { Regional } \\
\text { political } \\
\text { parties } \\
\text { advocating } \\
\text { independence } \\
\text { or maximum } \\
\text { autonomy }\end{array}$} & Left & & Candidatura d'Unitat Popular [Popular Unity Candidacy] (CUP) & \\
\hline & Centre left & Scottish National Party (SNP) & $\begin{array}{l}\text { Esquerra Republicana de Catalunya [Republican Left of Catalonia] } \\
\text { (ERC) }\end{array}$ & \\
\hline & Right & & $\begin{array}{l}\text { Partit Demòcrata Europeu Català [European Catalan Democratic } \\
\text { Party] (PDeCAT), known as Convergència Democràtica de } \\
\text { Catalunya [Democratic Convergence of Catalonia] (CDC) before } \\
\text { 2016. Note: CDC+UDC coalesced into Convergencia i Unió } \\
\text { [Convergence and Union] (CiU) 1978-2015 }\end{array}$ & $\begin{array}{l}\text { Nieuw-Vlaamse Alliantie [New Flemish Alliance] (N-VA) } \\
\text { (previously VU) }\end{array}$ \\
\hline & Far right & & & Vlaams Belang [Flemish Interest] (VB) \\
\hline \multirow{7}{*}{$\begin{array}{l}\text { Other main } \\
\text { regional } \\
\text { political } \\
\text { parties }\end{array}$} & Left & Scottish Greens & $\begin{array}{l}\text { Iniciativa per Catalunya Verds \& Esquerra Unida i Alternativa } \\
\text { [Initiative for a Green Catalonia and United and Alternative Left] } \\
\text { (ICV \& EUiA) }\end{array}$ & Groen [Green] \\
\hline & & & $\begin{array}{l}\text { Catalunya en Comú (CatComú)-Podem [Catalonia in Common-We } \\
\text { Can] }\end{array}$ & \\
\hline & Centre left & $\begin{array}{l}\text { Scottish Labour Party } \\
\text { Scottish Liberal Democrats }\end{array}$ & $\begin{array}{l}\text { Partit dels Socialistes de Catalunya [Socialist Party of Catalonia] } \\
\text { (PSC) }\end{array}$ & $\begin{array}{l}\text { Socialistische Partij Anders [Socialist Party-Differently] } \\
\text { (sp.a) (previously SP) }\end{array}$ \\
\hline & Right & Scottish Conservative Party & $\begin{array}{l}\text { Unió Democràtica de Catalunya [Democratic Union of Catalonia] } \\
\text { (UDC), dissolved 2017. Note: } C D C+U D C \text { coalesced into }\end{array}$ & $\begin{array}{l}\text { Open Vlaamse Liberalen en Democraten [Open Flemish } \\
\text { Liberals and Democrats] (Open VId) (previously VLD) }\end{array}$ \\
\hline & & & Convergencia i Unió [Convergence and Union] (CiU) 1978-2015 & Christen-Democratisch en Vlaams [Christian Democratic \\
\hline & & & Partit Popular de Catalunva [Pooular Party of Catalonia] (PPC) & \\
\hline & Far right & & & \\
\hline \multirow{17}{*}{$\begin{array}{l}\text { Year of } \\
\text { regional } \\
\text { elections and } \\
\text { subsequent } \\
\text { governments }\end{array}$} & 1999 & Scottish Labour Party & $\mathrm{CiU}(\mathrm{CDC}+\mathrm{UDC})$ & Coalition: VLD, SP, Agalev (Greens) and VU (until 2003) \\
\hline & 2000 & & & \\
\hline & 2001 & & & \\
\hline & 2002 & & & \\
\hline & 2003 & Scottish Labour Party & Coalition: PSC, ERC, ICV & \\
\hline & 2004 & & & Coalition: CD\&V, N-VA, sp.a and Open VLD \\
\hline & 2005 & & & \\
\hline & 2006 & & Coalition: PSC, ERC, ICV & \\
\hline & 2007 & Coalition: SNP-Scottish Liberal Democrats & & \\
\hline & 2008 & & & \\
\hline & 2009 & & & Coalition: CD\&V, N-VA and sp.a \\
\hline & 2010 & & $\mathrm{CiU}$ & \\
\hline & 2011 & SNP & & \\
\hline & 2012 & & $\mathrm{CiU}$ & \\
\hline & 2013 & & & \\
\hline & 2014 & & & Coalition: N-VA, CD\&V and Open Vld \\
\hline & 2015 & & Coalition: Junts pel Sí (CDC+ERC), with ad hoc support from CUP & \\
\hline
\end{tabular}




\section{Spatial planning in sub-state nationalist agendas}

We now analyse to what extent nationalist parties have mobilised spatial planning and territorial management issues in their discourses, and whether they have developed (distinct) planning and territorial management policy agendas as part of their claims. Our analysis is based on exploratory research conducted in the three territories between 2013 and 2018 using two main methods:

- qualitative content analysis of primary documentary sources including the electoral manifestos of the main nationalist parties at regional elections since 1999 (Scotland), 2004 (Flanders) and 2010 (Catalonia); key official publications on the Scottish referendum and on the right to self-determination in Catalonia; strategic planning policy documents; and statements by relevant organised interests (e.g. civil society organisations or professional associations in fields related to planning).

- 30 semi-structured interviews with key stakeholders involved in spatial planning and territorial management policies: officials from the (regional) ministries of planning; academic experts; elected members of the regional parliaments (in particular from nationalist parties); and representatives from professional planning associations and related interest groups.

\section{Scotland}

Following the 2011 elections, the SNP was able to form a majority government on the promise of a referendum on Scottish independence. In October 2012 the UK's Prime Minister and Scotland's First Minister signed an agreement on the terms of the referendum, which took place in September 2014. The prospect of establishing a progressive social policy in Scotland was at the core of the SNP's argument for independence (Béland and Lecours, 2008). The SNP is generally described as a moderate, left-of-centre party. Its supporters often associate Scottish national identity with notions of egalitarianism, social justice and progressive social policy preferences (Béland and Lecours, 2008), including greater support for state intervention, although the supposed prevalence of such values in Scottish society is debated (McCrone, 2017).

Spatial planning in Scotland acquired a relatively high profile on the agenda of the SNP governments, although it figured only intermittently in the party's electoral manifestos during this period. From 2010 onwards, the UK government - a coalition of Conservatives and Liberal Democrats - set out to reform the English planning system through the 2011 Localism Act, which dismantled strategic spatial planning initiatives in England. A divergence between the planning policy agendas of the Scottish and UK governments thus became more apparent (Tomaney and Colomb, 2013), although some similarities remained in the discourses of the two governments (e.g. an emphasis on 'sustainable economic growth' and efficiency in the planning permission process). Yet unlike the anti-planning rhetoric of the Conservatives, the SNP government was keen to state the value of planning as a positive means of steering spatial development. Respondents from the public and private sectors and from various political parties remarked that that there seems to be a "national consensus" about planning in Scotland, and that Scottish Conservatives have not sought to dismantle or vilify planning as has, at times, been the case in England.

The strategic and visionary element of planning supports the SNP's vision of an independent Scotland. The $3^{\text {rd }}$ National Planning Framework (NPF) for Scotland (Scottish Government, 
2014), published just before the independence referendum, contains a 30-year vision for the territory in support of sustainable economic growth and the transition to a low-carbon economy. It was presented as the spatial expression of the SNP government's Economic Strategy (Scottish Government, 2010), and emphasised the need to balance economic growth with environmental protection, the stewardship of natural resources and the development of renewable energy. Additionally, themes of social, regional and inter-generational equity figured prominently in the NPF and the Economic Strategy in ways that were absent in the UK government's National Planning Policy Framework for England (DCLG, 2012; Tomaney and Colomb, 2013). Interviewees stated that there were time pressures to finish NPF3 before the referendum of September 2014, and that it had to be "aspirational, offer something for all of Scotland, and avoid controversial and divisive developments" (Senior Planner, Scottish government). The preparation of NPF3 generated, according to an official involved in the process, healthy discussions about the geography of Scotland and how certain parts of Scotland are represented. The identification of strategic national development projects as part of the document was, additionally, characterised by relative consensus. For instance, major infrastructure proposals for the Highlands and Islands were all accepted, in order to counterbalance the weight of Central Belt.

The NPF (and associated policy guidance) is supposed to shape planning decisions in a range of sectors such as economic development, regeneration, energy, environment, transport and digital infrastructure. Whether it effectively influences the investment decisions of public authorities and private investors remains unproven. The Scottish Government's room for manoeuvre is limited by its inability to borrow directly on capital markets to fund infrastructure projects, and the UK Parliament's remaining competences in key policy areas such as taxation, energy and airports. Energy policy is a source of contention because the SNP rejects nuclear power and fracking for shale gas. The devolution of spatial planning allowed the Scottish Government to foster a de facto renewable energy policy (which already makes up $40 \%$ of Scotland's electricity generation), by promoting the development of wind farms, banning fracking and refusing the building of new nuclear power stations. But the Scottish Government's ambitions come up against the constraints of the national electricity grid, which remains a UK government regulatory responsibility.

Prior to the 2014 Referendum, the Scottish Government published its prospectus for independence in a document entitled Scotland's Future (Scottish Government, 2013). It set out its ambitions 'for the type of economy and society that captures Scotland's distinct values and build distinct economic, industrial and social policies which reflect these aims' (p. 94). It asserted that independence would allow 'an alternative economic policy' to that 'which disproportionately benefits London and the South East of England' (p. xii), leading to stronger connections between urban and rural, island and mainland, national and international. Independence would also enable the alignment of transport policy with energy policy to achieve declared carbon reduction targets.

Much of the case for independence rested on the benefits arising from full control of Scotland's rich natural resources, such as the seabed and oil and gas reserves, claimed to be 'central to our identity as a country and as a people' (p. 288). It was proposed that independence would 'enable a regulatory approach that is tailored to specific Scottish conditions that influence the costs of keeping homes warm, such as our climate, our mix of urban, rural and remote communities and our distinctive housing stock' (p. 169). It was asserted that 'the harsher Scottish climate and the challenges of heating remote homes call 
for an ambitious approach to energy efficiency and carbon emissions reduction' (p. 167). It is worth nothing that this narrative is, in the UK context, not unique to Scotland: Jones and Ross (2016) have analysed how nationalists in Wales have claimed that 'sustainable development that is allegedly more attuned to Welsh national values and identities', and 'is being used to imagine new and possibly more inclusive kinds of futures for the Welsh nation' (p. 54).

The Scottish independence referendum took place on 18 September 2014. Independence was rejected by $55 \%$ to $45 \%$. After the referendum, there were further changes to the devolution settlement as the full provisions of the 2012 Scotland Act were rolled out. A commission was set up to prepare proposals for further devolution (Smith Commission, 2014), whose recommendations were included in the revised Scotland Act, 2016. It gave extra power to the Scottish Parliament, e.g. the management of the Crown Estate in Scotland, the setting of rates and thresholds of Income Tax, Air Passenger Duty, the licensing of onshore oil and gas extraction, and rail franchising.

After 2014, some planning-related activities of the Scottish Government strengthened the contrast with the planning agenda in England, in particular through the Community Empowerment Act 2015 and the Land Reform Act 2016, which grants some power to the Scottish government to force the sale of private land to community bodies so that land 'can be best managed in the public interest to ensure it is of benefit to all of the people of Scotland' (SNP, 2015: 32), a contentious issue in a country where large landlords historically own a sizable part of the territory (for a discussion, see Wightman, 2019). These reforms illustrate an approach to 'localism' and community empowerment by the SNP which is markedly different than the 'new localism' agenda of the UK government in England. A further reform of Scottish planning legislation was announced by the Scottish government, with a new Planning (Scotland) Bill presented to the Parliament in 2017. The legislation had a fractious passage through the Scottish Parliament, with the government claiming it streamlined the planning process, while opponents asserting it centralised power at the expense of local councils and communities (BBC News, 2019; Tomaney et. al. 2019).

\section{Catalonia}

In 2006 a new Statute of Autonomy for Catalonia was approved in the Spanish parliament, but judicially challenged by the right-wing Partido Popular (PP). In 2010 the Spanish Constitutional Court culled significant parts of the Statute, which led to massive protests in Catalonia and an increase in support for independentist parties (Table 2). Following the regional election of 2010 (and others in 2012, 2015 and 2017), Catalonia has been governed by pro-independence parties spanning from the far left to the right of the political spectrum (see Table 2), while the Spanish government was governed by the PP from 2011 until 2018. The Catalan separatist movement is additionally fuelled by powerful civil society associations and movements (such as the Catalan National Assembly), able to mobilise large crowds for the Catalan National Day on $11^{\text {th }}$ September (Crameri, 2015). These organisations helped the Catalan government organise a referendum on self-determination on 1 October 2017, albeit declared illegal by the Spanish government. The vote was violently repressed by the Spanish police and followed by the temporary suspension of Catalan regional autonomy and enforcement of direct rule until new regional elections in December 2017, at which proindependence parties, reflecting the deep divisions in Catalan society, retained only a small majority. 
Three phases can be identified in the planning and territorial management policy agenda of Catalan governments since 2010. The years 2010-2012 were marked by a liberalising approach. The economic crisis was used as a legitimising argument to support large-scale urban development projects that were highly controversial in socio-economic and environmental terms. New laws were passed to partly deregulate development control procedures. Austerity led to the freezing of the urban regeneration programme set up by the previous government. The revision of the General Territorial Plan of Catalonia - started in 2009 - was halted and some planning-related public agencies were dissolved. Nevertheless, several laws passed by the previous government were retained, in particular on landscape protection.

Between 2012 and 2017, the liberalising drive of the Catalan government was somewhat weakened, partly to secure the support of other pro-independence parties (ERC and CUP, respectively on the centre-left and far left of the political spectrum) in the governing coalition. The manifestos of the main Catalan parties for the 2012 and 2015 regional elections reveal a degree of discursive convergence around objectives such as sustainable mobility; a compact urban model; tackling climate change; better management of natural resources; landscape protection; supporting renewable energy; and increasing affordable housing (with the exception of the PP, which does not mention these issues). In practice, however, as revealed in interviews with members of the Catalan Parliament, there have been tensions within the governing coalition regarding particular policy issues (e.g. ring roads and motorway extensions).

The regional election campaign of 2015 focused on the right to self-determination and brought to power a coalition named Junts pel Sí ("Together for Yes"), which focused its activities on enforcing that right and setting a 'roadmap' to independence. This generated fierce opposition from non-independentist parties, and meant that debates on key substantive policy issues, largely, have taken the back seat in the Catalan Parliament. Draft proposals for a new regional 'Law of Territory' and 'Law on the Planning of Coastal Areas' were launched in 2014-15, but progress stopped in 2017 after the 'unauthorised' referendum. The Catalan government's White Paper on the so-called 'national transition' (GenCat, 2014) focuses on the steps to be taken to exercise the right to self-determination and achieve independence. It refers to the creation of 'state structures' (e.g. tax collection and social security institutions) as well as measures to ensure the continuity of energy, transport and water supply. But it does not contain references to any substantive policy objectives for its nation-building project, which contrasts starkly with the detailed policy debates which preceded the Scottish referendum.

The pro-independence forces in Catalonia mainly mobilise claims about national identity and sense of community (i.e. language and education policy); economic viability (fiscal relations with the central state); and future opportunities in a global world (issues of infrastructure, especially transport) (Bel, 2015). Spatial planning in a strict sense does not figure prominently in those arguments. None of the electoral manifestos of pro-independence parties included an overall vision of the territory in the sense of a 'territorial model for Catalonia' which would offer a framework for all public policies (SCOT, 2015: 6), with the possible exception of the left-wing anti-capitalist party, CUP, which offers a radical vision of decentralised endogenous development and de-growth for Catalonia, with radical policies in relation to energy, water and food sovereignty. The strong territorial imbalances within Catalonia remain surprisingly unaddressed (e.g. rural depopulation or the lack of attention to the Southern part of 
Catalonia, often forgotten in nationalist imaginary). As a senior Catalan planning scholar argued in a 2016 interview, "spatial planning is not used for a national project".

The lack of attention of the pro-independence political forces towards spatial planning contrasts strongly with the central importance of urban planning and related fields in the agenda of the parties which have governed Barcelona for most of the post-Franco period: the Socialist Party until 2011, and after 2015, the new political force Barcelona en Comú. The latter has placed the right to housing, improvements to public transport, tackling air pollution, public energy and water management, and the return to a more 'socially focused' urban planning at the heart of its agenda, arguing that distributional questions should come first in the city's politics - not the 'national' question. Additionally, an emerging metropolitan-scale planning vision (Pla Estratègic Metropolità de Barcelona) has been developed by a not-forprofit association promoted by Barcelona City Council and the Metropolitan Area of Barcelona, as an instrument for identifying the potential of the city-region's territory in the medium term, thus pointing towards a specifically metropolitan 'planning imaginary'.

These differences between the urban/metropolitan and regional political agendas reflect a long-standing historical cleavage in the electoral-political geography of Catalonia, between the Barcelona metropolitan region and the rest of the territory. In the former, left-wing, nonindependentist parties gain the most votes, whereas in the latter, regionalist or proindependence parties (both right- and left-wing) are most supported. The share of the votes for pro-independence parties has, however, increased in Barcelona from the early 2010s onwards. These parties have had to change their traditionally hostile vision of the city, and of metropolitan and urban issues, as a result. As expressed by a member of the Catalan Parliament from the ERC party interviewed in 2016, there is "no new nation without a strong capital city".

Territorial management issues are nonetheless present in the narrative of pro-independence parties in relation to three themes. First, there are strong grievances about the 'unfair' fiscal transfers and distribution of public investment by the Spanish state between Autonomous Communities. Catalan governments have continually criticised the centralising transport investment policies of successive Spanish governments, historically favouring the convergence of networks towards Madrid in what Bel $(2010,2011)$ terms a consolidation of the 'radial State' since the $17^{\text {th }}$ century. Nationalists declaim the lack of financial support by the Spanish state for the Mediterranean rail corridor (linking the South of Andalusia through Catalonia to the Rhone Valley) and for the secondary railway network in Catalonia, while demanding control over airport and port management. Second, the Spanish state and Catalan actors have clashed over the management of natural resources, notably water; such as the proposal by the PP government in 2000 to redirect water from the River Ebre which generated strong protests in Catalonia (although the then CiU-led Catalan government initially supported the proposal). Third, left-wing, pro-independence Catalan political parties and social groups associate control over natural resources with broader claims for a more egalitarian and ecologically-sensitive national project, reflecting historical linkages between the Catalan environmental movement and the Left-wing part of the independentist movement (Nogué, 1998).

\section{Flanders}


Flemish nationalism has its origins in the demand for equal status for the Dutch language in Belgium in relation to French, which was the language of the $19^{\text {th }}$ century ruling elite. After the Second World War, the rise of Flemish nationalism prompted the transformation of the Belgian state through a series of six constitutional reforms between 1970 and 2011, which have failed to quench Flemish demands for more autonomy. At present, around $58 \%$ of the population of Belgium is Dutch-speaking and 31\% French-speaking. In the early 2000s, two Flemish nationalist parties became increasingly popular: the Nieuw-Vlaamse Alliantie (N-VA), a right-wing party founded in 2001 out of the previous Volksunie (1954-2001), and the Vlaams Belang (VB), a far-right party (earlier called Vlaams Blok, that gained strength in the late 1980 s), which began to lose popularity after 2009 but regained $12 \%$ of the vote in the 2019 Belgian federal elections.

In 2004 the Flemish regional elections brought to power a coalition of Christian-Democrats, Social-Democrats and the N-VA. Since then the N-VA has continued to attract a strong vote at local, regional and national elections, and been part of all Flemish governing coalitions (Table 2). The N-VA does not openly advocate independence, but a confederal model for Belgium which would move 'the centre of gravity of the socio-economic policy ... to the federated entities so that they can implement a policy at the level of their own inhabitants and economy' (N-VA, 2019: np). Its manifestos express grievance about the level of fiscal redistribution between Flanders and Wallonia. The N-VA favours low tax and limited state intervention, in particular in land use management and private property rights. Under the leadership of Bart De Wever, the party moved to the right, with tougher stances on immigration and security. In its 2009 regional election programme, the N-VA also described itself as a 'green' party, advocating support for public transport and renewable energy - an emphasis which was lost thereafter.

Since 2004, Flanders has been governed by coalitions between the Christian Democrats $(C D \& V)$, Flemish nationalists (N-VA), and other parties (Table 2). The Flemish political consensus is often defined as 'right-wing', whereas the largest political party in Brussels and Wallonia is the Parti Socialiste. The notion of 'right-wing Flanders' and 'left-wing Wallonia' is a powerful trope in Belgian politics, although, arguably, this has less to do "with "objective" socio-economic differences, but rather with a curiously persistent identity construction' (De Wever, 2011: 4). In the coalition system, individual ministers have extensive autonomy over their policy domains. The ministry of Spatial Planning has moved between the VLD (19992009), N-VA (2009-2014) and CD\&V (2014-2019).

In this political context, since the 2000s land use planning has been blamed for hindering development, which has led to reforms facilitating greenfield development (Van den Broeck and Verachtert, 2016). The strategic spatial planning approach developed in the 1990s was weakened and spatial planning was reoriented towards the protection of private property, hampering 'the capacity of government to implement a coherent spatial policy and collective spatial projects' (Van den Broeck and Verachtert, 2016: 388). This reflected historic Flemish social and cultural preferences for private home ownership and unconstrained individual housebuilding, expressed in a popular distrust of government interference in planning (De Vries, 2015). This has been reflected in the enactment of widespread exceptions to zoning restrictions, a lax enforcement of planning regulations, local clientelist practices, and illegal constructions (Van den Broeck and Verachtert, 2016). 
In 2011, a process was launched to replace the Spatial Structure Plan for Flanders by a new 'Policy Plan for Town and Country Planning' (DRV, 2016), still underway at the time of writing. A Green Paper (DRV, 2012) set out key principles for the future plan, including the rejection of urban sprawl and preference for the protection of green spaces. A 2016 White Paper further acknowledged the spatially dispersed, sprawling and car-dependent urbanization pattern of Flanders, defining the key objective of the future plan as 'doing more with less space' (DRV, 2016) by stopping all new construction on unused open space by 2040. In July 2018, the Flemish Government approved the 'Strategic Vision' of the future Flanders Spatial Policy Plan (DRV, 2018), which confirmed the commitment to reduce greenfield development, although this has been undermined in practice by recent planning decisions (Tomaney and Colomb, 2014) and the pro-growth political agenda of Flemish governments since 1999.

The 'Strategic Vision' does not include any map or visualisations of future development patterns for the whole Flemish territory. Moreover, it contains a strong localist rhetoric, calling for 'provinces, cities and municipalities [to be] given more responsibilities' to 'determine for themselves which town and country planning projects they will focus on'. It abandons 'the notion of a strict planning concept, imposed by the Government of Flanders' (p. 30), and limits the role of the Flemish government to determining large-scale transformation projects. Inter-municipal cooperation is proposed to deal with issues such as water management, housing development and mobility management, but with little indication of how it should be incentivised. ${ }^{3}$

More notably, there has been little inter-regional cooperation at the political level between the three regions of Belgium on key, trans-regional planning issues. Before the decentralization of planning to the regions, the Belgian national planning system initially permitted a national plan, but none was ever produced. The lack of co-ordinated strategic planning to guide the growth of the Brussels metropolitan area is a particularly pressing issue, as its functional urban economy extends far beyond the administrative boundaries of the capital city-region. The Flemish government has been standing 'with its back to Brussels', as expressed by a senior planning scholar. Land use planning in the Flemish municipalities around Brussels is highly politicised and has been used as a mean of pursuing 'language wars' (Boussauw et al., 2013). As French has become the majority language in Brussels, in the Dutchspeaking 'Flemish Fringe' that encircles the city, there is resistance to the growth of new Francophone communities. The growth of the Brussels functional urban area and extended commuter flows is seen as posing a threat to the national (linguistic) identity of Flanders, and Flemish municipalities have used restrictive planning policies to contain the 'francisation' of their territory; for example, by attaching conditions to the sale of public land or social housing allocation (stipulating that prospective buyers or tenants should have a link to the municipality), or by setting height limits to new housing development (as done in the district of Brussels-Halle-Vilvoorde). In December 2011, the Flemish Government adopted a specific development perspective for the 'Flemish strategic area around Brussels' (VSGB), which delineates an urban growth boundary aimed at containing the growth of Brussels. The (Socialist) Minister-President of the Brussels-Capital Region subsequently filed a complaint with the federal Council of State against this plan in the summer 2012. 


\section{Conclusions. Spatial planning, sub-state nationalism and the politics of territory in Europe}

The three cases explored here reveal that spatial planning and territorial development issues can be mobilised politically to support the autonomist or separatist political agendas of substate nationalist parties. However, our research shows that such issues are rarely central compared to social or linguistic policy issues, although as the Flanders case shows, planning laws can be used as a means to prosecute language wars. Taking Béland and Lecours' (2008) analysis one step further, we showed that spatial planning and territorial management issues gained prominence in such agendas, sometimes indirectly, because they contain redistributive demands linked with inter-territorial fiscal transfers and, centrally, because they reflect the relationship between state, market and civic society in the management of land, wherein "models of society" (Faludi, 2007) and "worlds of welfare" (Esping-Andersen, 1990) are expressed. But, in none of the three cases do we witness the formulation of a cohesive and comprehensive spatial vision for the whole territory, although the NPF (in the Scottish case) comes closest to that. The absence of a strong spatial planning strategy 'does not necessarily imply the absence of a collective spatial project' (De Vries, 2015: 2160) though it may be an implicit one. The development of a coherent and overarching strategic spatial strategy and policy - if it exists - remains overshadowed by decisions taken in other policy areas and at other scales of government - for example large-scale road and rail infrastructure development, retail siting, and property taxation. In Flanders, for example, the 1997 RSV provided a long-term vision for the region but played a marginal role in the allocation of public resources (Van den Broeck, 2008; Tomaney and Colomb, 2014) - reflecting the 'missing link' between strategic plans, public budgets and projects witnessed in many other contexts (see Moore-Cherry and Tomaney, 2019, for the Irish case).

When comparing the findings from the three cases, it is clear that nationalist parties mobilise spatial planning and territorial management to varying extents and in diverse ways. In Scotland, the SNP's planning discourse has been more strategic, interventionist and positive compared to that of the N-VA in Flanders. The claim that Scottish political culture is more consensual, egalitarian and favourable to state intervention (than its English counterpart) figured prominently in the case for Scotland's independence. There is evidence of the performativity of such proclaimed values in the Scottish strategic planning discourse, in part as a reaction to the 'anti-planning' rhetoric of the Conservatives in England. In Flanders, the N-VA - in coalition with other right-wing political parties and influenced by landowners and the building sector (Van den Broeck and Verachtert, 2016) - has favoured the liberalisation of planning controls and shown scepticism about previous strategic planning approaches. The case of Catalonia is more ambiguous: because the three main parties advocating the right to self-determination are located from the radical left (CUP), via the moderate left (ERC) to the right of the political spectrum (PDCat), there are differences in policy agendas in relation to planning and territorial management policies, but also a degree of 'centrist' consensus because of the coalition dynamics between these different parties.

Our analysis thus shows that the observed differences between the three cases seem to depend on the political ideology of each nationalist party vis-à-vis the role of the state and the legitimacy of public policy interventions in market processes. Differences are rooted in the relative value which parties attach to particular objectives such as sustainability, the protection of private property, economic growth etc. The positioning of each party on the traditional left-right political spectrum, rather than their broader 'nationalist' disposition, 
seems to be more decisive in influencing the extent to which spatial planning is mobilised in their political discourse and policy agenda. In that regard, it is significant that the shift to strategic spatial planning which happened in the 1990s-2000s in the three regions was not pressed by regionalist or nationalist parties, but by coalitions of centrist, left-wing and/or green parties which broadly shared a progressive social-democratic and environmental agenda in relation to questions of territorial management, at a moment when existing models of urban growth and resource consumption were becoming increasingly criticised (in particular in Flanders and Catalonia).

This paper addresses the relative absence of a concern with the production of the territory in classic studies of nationalism, by focusing on the production of the national space through public policies related to the planning and organisation of the territory. The literature on nationalism notes the importance of the "homeland" to the nationalist project (Smith, 2001) and pays particular attention to the discursive aspects of nation building, but we noted how the spatial planning and geographical dimensions are comparatively neglected. In this paper we have sought to redress this lacuna using the lens of spatial planning to contribute to analyses of contemporary forms of sub-state nationalisms in Europe. Nations are imagined communities. We have shown how the 'shaping of territory' is an important aspect of nationalist politics in the three cases (albeit to a variable degree). Spatial planning has been an instrument to that end, although strategic ambitions often are defeated by day-to-day realpolitik. This paper thus draws attention to the role of spatial planning in envisioning and forming the national territory, while noting the considerable variation in how spatial visions are developed and subsequently materialised, reflecting the way national priorities are contested often along conventional left-right axes. We suggest this is a fruitful area for future comparative studies.

In future research, more attention needs to be paid to the social actors and economic interest groups which form the constituencies of regionalist and nationalist parties: first, their geographical distribution (which can offer insights into intra-regional divides, e.g. between metropolitan areas and other parts of the territory); second, how their characteristics influence their attitude to land, property, ecological issues or their pro- or anti-urban bias. As emphasised by De Vries in his insightful comparison of Dutch and Flemish planning cultures, the 'combination of urban morphology, actor constellations and societal values can shape the planning project in particular countries or regions', in particular 'the size and orientation of key actors in the land and property development process' (2015: 2161). There is a need to unpack the fraught spatial metaphors which are commonly used in political and media discourses through the 'recurring substitution of social actors with territorial abstractions': "rich regions", "poor regions", "Catalonia", "Spain", "Madrid" ... are metaphors continuously used to mask the fact that what is in competition are not territories, but social groups, economic interests and political projects' ( $\mathrm{Nel} \cdot \mathrm{lo}, 2013 \mathrm{~b}$ : 49-50, authors' translation from Spanish). Finally, while we focused here on policy discourses and agendas, further inquiry is needed into the implementation and impacts of policies enacted by governments led (or coled) by nationalist parties, and into the extent of policy distinctiveness in spatial planning and territorial management - as there is often a large gap between promises and the reality of public policy implementation. 


\section{Acknowledgements}

We would like to thank all the interviewees in Catalonia, Flanders and Scotland who generously gave us their time and insights. We are grateful to colleagues who offered constructive comments on earlier versions of this paper, which were presented at seminars at the London School of Economics, Birmingham University, Institut d'Aménagement et d'Urbanisme de Lille, University of Santiago de Compostela, Open University of Catalonia, and $\mathrm{KU}$ Leuven. Our thanks to the three anonymous referees and editors of the Themed Issue for their positive, detailed and extremely helpful comments. We would like to thank the UCL Bartlett School of Planning, as well as the former Institut d'Estudis Autonòmics (now Institut d'Estudis de I'Autogovern) of the Generalitat de Catalunya, for small travel and research grants which supported a number of field visits. 


\section{References}

Agnew, J. (1987) Place and Politics: The Geographical Mediation of State and Society. Boston: Allen and Unwin.

Albrechts, L. (1999) Planners as catalysts and initiators of change: The new structure plan for Flanders. European Planning Studies, 7(5): 587-603.

Albrechts, L. (2001) Devolution, regional governance and planning systems in Belgium. International Planning Studies, 6(2): 167-82.

Albrechts, L., Healey, P. and Kunzmann, K. (2003) Strategic spatial planning and regional governance in Europe. Journal of the American Planning Association, 69(2): 113-129.

Allmendinger, P. (2001) The head and the heart. National identity and urban planning in a devolved Scotland. International Planning Studies, 6(1): 33-54.

Allmendinger P. (2006) Escaping policy gravity: the scope for distinctiveness in Scottish spatial planning. In M. Tewdwr-Jones and P. Allmendinger (eds) Territory, Identity and Spatial Planning: Spatial Governance in a Fragmented Nation. London: Routledge, pp. 153-66.

Allmendinger P. and Haughton G. (2010) Spatial planning, devolution, and new planning spaces. Environment and Planning C, 28(5): 803-18.

Anderson, B. (1983) Imagined Communities. London: Verso.

Bel, G. (2010) España, Capital Paris. Barcelona: Destino.

Bel, G. (2011) Infrastructure and nation building: The regulation and financing of network transportation infrastructures in Spain (1720-2010). Business History, 53(5): 688-705.

Bel, G. (2015) Disdain, Distrust, and Dissolution. The Surge of Support for Independence in Catalonia. Eastbourne: Sussex Academic Press.

Béland, D. and Lecours, A. (2008) Nationalism and Social Policy: The Politics of Territorial Solidarity. Oxford: Oxford University Press.

Billig, M. (1995) Banal Nationalism. London: Sage.

Boussauw, L, Allaert, G. and Witlox, F. (2013) Colouring inside what lines? Interference of the urban growth boundary and the political-administrative border of Brussels. European Planning Studies, 21(10): 1509-27.

Brenner, N. (2004) New State Spaces. Oxford: Oxford University Press.

Breuilly, J. (1993) Nationalism and the State. $2^{\text {nd }}$ ed. Manchester: Manchester University Press. 
Campbell, S. (1996) Green cities, growing cities, just cities? Urban planning and the contradictions of sustainable development. Journal of the American Planning Association, 62(3): 296-312.

Colomb, C. and Tomaney, J. (2015) Territorial politics, devolution and spatial planning in the UK. Planning Practice \& Research, 31(1): 1-22.

Colomb, C., Bakke, K. and Tomaney, J. (2014) Shaping the territory in Scotland, Catalonia and Flanders. Working Paper No. 5, UCL European Institute. Online: https://www.ucl.ac.uk/european-institute/news/2012/aug/shaping-territory-scotlandcatalonia-and-flanders

CEC Commission of the European Communities (1997). The EU Compendium of Spatial Planning Systems and Policies. Luxembourg: Office for Official Publications of the European Communities.

Crameri, K. (2015) Political power and civil counterpower: the complex dynamics of the Catalan independence movement. Nationalism and Ethnic Politics, 21(1): 104-20.

DCLG Department for Communities and Local Government (2012) National Planning Policy Framework. London: DLCG.

De Decker, P. (2011) Understanding housing sprawl: The case of Flanders, Belgium. Environment and Planning A, 43(7): 1634-54.

De Vries, J. (2015) Planning and culture unfolded: the cases of Flanders and the Netherlands. European Planning Studies, 23(11): 2148-64.

De Wever, B. (2011) Right-Wing Flanders, Left-Wing Wallonia? Is This So? If So, Why? And Is It A Problem? Re-Bel e-book 12. Online: https://www.rethinkingbelgium.eu/rebelinitiative-files/ebooks/ebook-12/Re-Bel-e-book-12.pdf

DRV Departement Ruimte Vlaanderen (2012) Green Paper: Flanders in 2050: Human Scale in a Metropolis? Spatial Policy Online: https://www2.ruimte.vlaanderen.be/ruimtelijk/docs/groenboek\%20ruimtelijke\%20orde ning\%20EN\%20DEF.pdf

DRV (2016) Working together on the space of tomorrow. Brochure to the White Paper on the Spatial Policy Plan for Online: https://www.ruimtevlaanderen.be/Portals/108/WhitePaperSpatialPolicyPlanFlanders br ochure2017 1.pdf

DRV (2018) Strategische Visie. Beleidsplan Ruimte Vlaanderen. Online: https://www.ruimtevlaanderen.be/Portals/108/Strategische Visie rgb 1.pdf

Esping-Andersen, G. (1990) The Three Worlds of Welfare Capitalism. Cambridge: Polity Press. 
Etherington, J. (2003) Nationalism, National Identity and Territory. The Case of Catalonia. Unpublished PhD Dissertation. Department of Political Sciences. Barcelona: Universitat Autònoma de Barcelona.

Etherington, J. (2010) Nationalism, territoriality and national territorial belonging. Papers: Revista de Sociologia, 95(2): 321-39.

Faludi, A. (2007) The European model of society. In: A. Faludi (ed.) Territorial Cohesion and the European Model of Society. Cambridge, MA: Lincoln Institute of Land Policy.

Gellner, E. (1983): Nations and Nationalism. Ithaca: Cornell University Press.

Generalitat de Catalunya (2014) Llibre Blanc de la Transició Nacional de Catalunya. Síntesi. Barcelona: Generalitat de Catalunya.

Hewitt, R. (2011) Map of the Nation. A Biography of the Ordnance Survey. London: Granta.

Hooson, D. (ed.) (1994) Geography and National Identity. Oxford: Blackwell.

Jones'-R. and Ross, A. (2016) National sustainabilities. Political Geography, 51: 53-62.

Keating, M. (2005) Policy divergence and convergence in Scotland under devolution. Regional Studies, 39(4): 453-63.

Keating, M. (2008) Thirty years of territorial politics. West European Politics, 31(1-2): 60-81.

Keating, M. (2013) Rescaling the European State. The Making of Territory and the Rise of the Meso. Oxford: Oxford University Press.

Keating, M., Cairney, P. and Hepburn, E. (2009) Territorial policy communities and devolution in the United Kingdom. Cambridge Journal of Regions, Economy and Society, 2(1): 51-66.

Knieling, J. and Othengrafen, F. (eds) (2009) Planning Cultures in Europe. Decoding Cultural Phenomena in Urban and Regional Planning. Farnham: Ashgate.

Lloyd, G. and Peel, D. (2009) New Labour and the planning system in Scotland: an overview of a decade. Planning Practice \& Research, 24(1): 103-18.

McCrone, D. (2017) The New Sociology of Scotland. London: Sage.

Moore-Cherry, N. and Tomaney, J. (2019) Spatial planning, metropolitan governance and territorial politics in Europe: Dublin as a case of metro-phobia? European Urban and Regional Studies, 26(4): 365-381.

Morphet, J. and Clifford, B. (2014) Policy convergence, divergence and communities: The case of spatial planning in post-devolution Britain and Ireland. Planning Practice \& Research, 29(5): 508-24. 
Nadin, V. and Stead, D. (2008) European spatial planning systems, social models and learning. disP - The Planning Review, 44: 35-47.

Nel·lo, O. (ed.) (2003) Aquí no! Els conflictes territorials a Catalunya. Barcelona: Empúries.

Nel·lo, O. (2012) Ordenar el Territorio. La Experiencia de Barcelona y Cataluña. València: Tirant lo Blanch.

Nel·lo, O. (2013a) Barcelona y Cataluña: las raíces del debate sobre el policentrismo del sistema urbano catalán. Ciudad y Territorio. Estudios Territoriales, 176: 317-332.

Nel·lo, O. (2013b) La crisis catalana: orígenes y alternativas. In: Gómez Mendoza, J., Lois Gonzáles, R. and Nel·lo Colom, O. (eds) Repensar el Estado. Crisis económica, conflictos territoriales e identidades políticas en España. Santiago de Compostela: Universidad de Santiago de Compostela, pp. 41-52.

Nel·lo, O. (2015) Barcelona i Catalunya, de nou. Blog post, 10 August. http://oriolnello.blogspot.com/2015/08/barcelona-i-catalunya-de-nou.html

Newman, P. and Thornley, A. (1996) Urban Planning in Europe: International Competition, National Systems and Planning Projects. London: Routledge.

Nogué, J. (1998) Nacionalismo y Territorio. Lleida: Milenio.

Nogué, J. and Vicente, J. (2004) Landscape and national identity in Catalonia. Political Geography, 23(2): 113-32.

Nogué, J. and Wilbrand, S. (2010) Landscape, territory, and civil society in Catalonia. Environment and Planning $D, 28(4)$ : 638-52.

N-VA (2019) Frequently Asked Questions. Online: https://english.n-va.be/frequently-askedquestions

Paasi, A. (1997) Geographical perspectives on Finnish national identity. GeoJournal, 43(1): 4150.

Peel, D. and Lloyd, G. (2007) Civic formation and a new vocabulary for national planning. International Planning Studies, 12(4): 391-411.

Rittel, H.W.J. and Webber, M. (1973) Dilemmas in a general theory of planning. Policy Sciences, 4(2): 155-169.

Rokkan, D. and Urwin W. (1983) Economy, Territory, Identity: Politics of West European Peripheries. London: Sage.

Rodríguez-Pose, A. and Sandall, R. (2008) From identity to the economy: analysing the evolution of the decentralisation discourse. Environment and Planning C, 26(1): 54-72.

Schama, S. (1995) Landscape and memory. London: Vintage. 
SCOT Societat Catalana d'Ordenació del Territori (2015) Fòrum 2012 Catalunya 21: "Territori i Urbanisme. Estat i Alternatives". Document d'alternatives. Barcelona: SCOT.

Scott, J.C. (1998) Seeing like a State. New Haven, CT: Yale University Press.

Scottish Government (2010) A Low Carbon Economic Strategy for Scotland. Online: https://www.webarchive.org.uk/wayback/archive/20170701133421/http://www.gov.sco t/Publications/2010/11/15085756/0

Scottish Government (2013) Scotland's Future. Online: https://www2.gov.scot/resource/0043/00439021.pdf

Scottish Government (2014) Ambition, Opportunity, Place: Scotland's Third National Planning Framework. Online: https://www.gov.scot/publications/national-planning-framework-3/

Smith, A. (2011) Nationalism: Theory, Ideology, History. Cambridge: Polity.

Tewdwr-Jones, M. and Allmendinger, P. (eds) (2006) Territory, Identity and Spatial Planning: Spatial Governance in a Fragmented Nation. London: Routledge.

Tomaney, J. and Colomb, C. (2013) Planning for independence? The evolution of spatial planning in Scotland and growing policy differences with England. Town and Country Planning, 82(9): 371-73.

Tomaney, J. and Colomb, C. (2014) Planning in a disunited kingdom. Town and Country Planning, 83(2): 80--83.

Tomaney, J. and Colomb, C. (2018) Devolution and planning. In: J. Ferm and J. Tomaney (eds) Planning Practice: Critical Perspectives from the UK. London: Routledge, pp. 20-35.

Tomaney, J., Natarajan, L., Ilies, E. and Hamiddudin, I. (2019) Towards a second generation of spatial planning in the UK? Town and Country Planning, 88(11): 457-461.

Van Den Broeck, P. (2008) The changing position of strategic spatial planning in Flanders. A socio-political and instrument-based perspective. International Planning Studies, 13(3): 261-83.

Van den Broeck, P. and Verachtert, K. (2016) Whose permits? The tenacity of permissive development control in Flanders. European Planning Studies, 24(2): 387-406.

Van den Broeck, P., Moulaert, F., Kuhk, A., Lievois, E. and Schreurs, J. (2014) Spatial planning in Flanders. Serving a by-passed capitalism? In: H. Blotevogel, P. Getimis, and M. Reimer (eds) Spatial Planning Systems and Practices in Europe: Towards Multiple Trajectories of Change. London: Routledge, p. 190-209.

Weber, E. (1976) Peasants into Frenchmen: The Modernization of Rural France 1870-1914. Palo Alto: Stanford University Press.

Wightman, A. (2019) Land Matters [Blog]. Online: http://www.andywightman.com/ 
Williams, C.H. and Smith, A.D. (1983) The national construction of social space. Progress in Human Geography, 7(4): 502-18.

\footnotetext{
${ }^{1}$ We use the word 'nationalist' in a neutral, non-pejorative sense to refer to political and social forces which advocate more autonomy, or secession, for their region/nation from the larger state of which it is a part.

${ }^{2}$ We are grateful to one of the anonymous referees for raising this point.

${ }^{3}$ The regional government has set up some funding to support such inter-municipal cooperation projects (e.g. Strategic Projects REKOVER in Kortrijk, Regionet in Leuven, the City Region of Turnhout and the City Region of Antwerp).
} 